\title{
Organizacja opieki zdrowotnej dla pracowników KC PZPR i CRZZ (1955-1980)
}

\author{
Organization of health care for the employees \\ of the KC PZPR and CRZZ (1955-1980)
}

\begin{abstract}
Summary
The publication presents the history and organization of institutions responsible for health care of the employees of the Central Committee of PZPR and CRZZ - Poliklinika Pracowników Komitetu Centralnego Polskiej Zjednoczonej Partii Robotniczej (KC PZPR) i Centralnej Rady Związków Zawodowych (CRZZ) and her successor Przychodnia Pracownicza KC PZPR i CRZZ. The main part of the work presents the history of the institutions, their organization and scope of activity. The bibliographical note presents such issues as: circumstances in which documents were found, management of documentation in the institutions and the condition of documents. The study based on previously unknown and unexplored archival material.
\end{abstract}

Slowa kluczowe: Poliklinika, Przychodnia Pracownicza, KC PZPR, CRZZ, opieka zdrowotna, PRL

Keywords: Polyclinic, Worker Clinic, Central Committee of PZPR, CRZZ, healthcare, PRL

Charakterystycznym elementem powojennego systemu służby zdrowia była organizacja branżowej opieki zdrowotnej dla poszczególnych grup zawodowych. Najbardziej znanymi w ten sposób uprzywilejowanymi grupami były wszelkiego rodzaju służby mundurowe oraz pracownicy kolei państwowych. W zupełnym cieniu zaś znalazła się opieka zdrowotna dla pracowników partyjnych i związkowych central Komitetu Centralnego Polskiej Zjednoczonej Partii Robotniczej (KC PZPR) i Centralnej Rady Związków Zawodowych (CRZZ). Poznanie ta- 
kich aspektów, jak dzieje Polikliniki Pracowników KC PZPR i CRZZ oraz Przychodni Pracowniczej KC PZPR i CRZZ, ich organizacji oraz zakresu działalności stało się możliwe dzięki uratowaniu - niemalże w ostatniej chwili - materiału źródłowego powstałego w ww. podmiotach.

\section{Powstanie Polikliniki Pracowników KC PZPR i CRZZ i jej struktura organizacyjna}

Do czasu powołania w drugiej połowie 1955 r. Polikliniki Pracowników KC PZPR i CRZZ opiekę lekarską pracowników KC PZPR i CRZZ zapewniały dwie oddzielne placówki - Poliklinika KC PZPR (ul. Wiejska 18, Warszawa) i Poliklinika CRZZ (ul. Mazowiecka 6/8, Warszawa) ${ }^{1}$. Po scaleniu nowa instytucja stała się zależna od trzech organów. Nadrzędną rolę pełnił Wydział Zdrowia dla Warszawy-Śródmieścia $(\mathrm{WZ})^{2}$, który opłacał częściowo etaty personelu medycznego oraz dostawy lekarstw i materiałów medycznych. Mimo tego, że WZ dysponował jedynie 1/3 składników majątkowych Polikliniki był jej faktycznym zwierzchnikiem w ramach ówczesnego systemu ochrony zdrowia. Pod względem kadrowo-administracyjnym Poliklinika była podporządkowana Przychodni Obwodowej Śródmieście „Północ”, przez co, gdy planowano i rozdzielano fundusze, była traktowana na równi $\mathrm{z}$ ambulatoriami przy instytucjach, $\mathrm{tj}$. niezbyt priorytetowo. WZ stał na stanowisku, że ciężar finansowania powinny wziąć na siebie instytucje korzystające $\mathrm{z}$ takich ambulatoriów. Taki model strukturalno-finansowy nie sprawdzał się w funkcjonowaniu Polikliniki, która w rzeczywistości świadczyła nie tylko doraźną pomoc ambulatoryjną, lecz także specjalistyczną. W dodatku rejonem jej działania nie był tylko jeden zakład czy dzielnica, ale w praktyce całe miasto i jego okolice. W związku z tym kierownictwo Polikliniki starało się o zmianę tego stanu na rzecz uzyskania statusu samodzielnej placówki wielospecjalistycznej lub przynajmniej obwodowej. Szansa na taką zmianę pojawiła się jednak dopiero w 1975 r. $^{3}$ Pozostałymi instytucjami finansującymi Poliklinikę były KC PZPR i CRZZ, które były jednocześnie głównymi świadczeniobiorcami placówki. $\mathrm{Z}$ ich budżetów finansowano pensje pracowników administracyjnych, niepełnozatrudniony personel me-

\footnotetext{
${ }^{1}$ Biblioteka Narodowa, Biuro Sekretariatu KC PZPR, Notatka dotycząca Polikliniki KC PZPR, Warszawa 22 VIII 1955, s. 1-2.

${ }^{2}$ Wydział Zdrowia Dzielnicowej Rady Narodowej, później Wydział Zdrowia i Opieki Społecznej Dzielnicy Warszawa-Śródmieście.

${ }^{3}$ Poliklinika Pracowników KC PZPR i CRZZ, Dokumenty dot. przekształcenia Polikliniki Pracowników KC PZPR i CRZZ w Przychodnię Pracowniczą KC PZPR i CRZZ, sygn. $426 / 2$, poz. 1-6.
} 
dyczny, zakupy sprzętu medycznego oraz modernizację pomieszczeń. Mimo posiadania łącznie 2/3 wkładu majątkowego obie te instytucje sprawowały jedynie nadzór administracyjny w postaci Komisji ds. Polikliniki KC PZPR i CRZZ. W jej skład wchodzili kierownik Wydziału Ogólnego (WO) KC PZPR i kierownik Zespołu Administracyjno-Gospodarczego CRZZ. Komisja miała decydujący głos w takich sprawach, jak zatwierdzanie preliminarzy budżetowych, rocznych sprawozdań i bilansów, podwyżek wynagrodzeń, regulaminów i instrukcji dotyczących Kierownictwa i Kolegium Polikliniki.

Organem zarządzającym bieżącą pracą placówki było Kierownictwo Polikliniki, na którego czele stał kierownik. Podlegali mu bezpośrednio: lekarze poszczególnych specjalizacji, lekarze konsultanci, Gabinet Zabiegowy, Pracownia RTG, Pracownia EKG, Fizykoterapia, Pracownia Protetyki Stomatologicznej, Pracownia Badań Laboratoryjnych, Apteka, Rejestracja, Administracja Polikliniki, Poradnia dla Dzieci i Młodzieży oraz punkty lekarskie, stomatologiczne i pielęgniarskie w gmachach: KC PZPR, CRZZ, Wyższej Szkoły Nauk Społecznych (WSNS). W 1974 r. nastąpiła zmiana i Polikliniką w miejsce Kierownika zaczął zarządzać Dyrektor. Była to jednak tylko modyfikacja tytulatury, za którą nie szły żadne zmiany organizacyjne. Dokonano jej zresztą w trakcie pełnienia funkcji przez tą samą osobę - dr. med. Bohdana Tadeusza Popławskiego, który 1 sierpnia 1972 r. zastąpił zmarłego pierwszego kierownika - dr. Zygmunta Kwiecińskiego ${ }^{4}$.

Organem doradczym, wspomagającym Kierownika, było Kolegium Polikliniki KC PZPR i CRZZ ${ }^{5}$. Było ono powoływane przez kierownika Polikliniki. W jego skład wchodzili: kierownik Polikliniki, Sekretarz Podstawowej Organizacji Partyjnej (POP) PZPR Polikliniki, przewodniczący Rady Zakładowej, kierownik Poradni dla Dzieci i Młodzieży, kierownik Zespołu Dentystycznego, przełożona pielęgniarek i st. referent ds. administracyjno-gospodarczych. W przypadku nieobecności wyżej wymienionych w posiedzeniach kolegium brali udział wyznaczeni przez nieobecnych zastępcy. Kierownik mógł bez konsultacji dołączać do składu Kolegium inne osoby. Na posiedzenia mogły być również zapraszane, w celu zreferowania danego zagadnienia, osoby spoza Kolegium, jednak miały one wówczas tylko głos doradczy. Posiedzenia Kolegium zwoływano według potrzeby, jednak przynaj-

${ }^{4}$ Poliklinika Pracowników KC PZPR i CRZZ, Sprawozdanie za rok 1972, 1973, sygn. 426/6.

5 Poliklinika Pracowników KC PZPR i CRZZ, Instrukcja o organizacji o zakresie czynności Kolegium Polikliniki KC PZPR i CRZZ, 12 VII 1971, sygn. 426/1. 


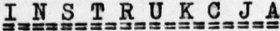 \\ OORGANIZAC JI I ZAKRESIE CZYNNOSOI I KOIEGIUM}

POLIKLINIKI PRACOWNIKOW $\mathrm{KC}=P Z P R=I$ PRZZ

1. Instrukcja ta reguluje organizacje, zakres czynności oraz metodyke pracy Kolegium Polikliniki Pracowników KK PZPR i CRZZ, zwanego w dalszej części instrukcji "Kolegium".

2. Stosownie do § 15 "Regulaminu wewnętrznego Polikliniki Pracowników KC PZPR i CRZ"n:

a - Kolegium powołuje Kierownik Polikliniki.

b - Kolegium jest organem doradczym Kierownika Polikliniki.

3. W skład Eolegium wchodza z urzędu:

a - Sekretarz POP Polikliniki

b - Przewodnicząca Rady Zakładowej

c - Kierownik Poradni dla Dzieci

d - Kierownik Zespołu Dentystycznego

e - Przełożona Pielęgniarek

f - St.Referent d/s Administracyjno-Gospodarczych.

4. W skład Kolegium mogą być również powołane inne osoby $\mathrm{w} / \mathrm{g}$ uznania Kierownika Polikliniki.

5. W posiedzeniach Kolegium mogą brać udział, z głosem doradczym, osoby $z$ poza składu Kolegium, zaproszone przez Kierownika Polikliniki celem rozszerzenia wiadomości w omawianych zagadnieniach lub celem złożenia wyjaśnień.

6. Wrzypadku nieobecności osób wymienionych w 314 w posiedzeniu Kolegium biora udział osoby przez nich wyznaczone.

7. Kierownik Polikliniki otwiera, prowadzi i zamyka posiedzenia Kolegium.

8. W przypadku służbowej nieobecności Kierownika Polikliniki wszelkie uprawnienia jego odnośnie Kolegium Przejmuje Zastępca Kierownika Polikliniki.

9. Posiedzenia Kolegium zwołuje Kierownik Polikliniki zależnie od potrzeby, lecz nie rzadziej niz raz na kwartał, podając członkom Kolegium porządek dzienny.

10. Skład Kolegium podaje Kierownik Polikliniki do wiadomości ogółu pracowników.

11. Do zakresu działania Kolegium należy:

a - wysuwanie nazwisk kandydatów do nagród pieniężnych 1 rzeczowych oraz odznaczeń państwowych 1 resortowych

b - omawianie zagadnier organizacyjnych Polikliniki

c - omawianie pracy fachowej Polikliniki

d - wysuwanie wniosków nowatorskich 1 usprawnień

- - wysuwanie wniosków dotyczących wysokości, podwyższania lub zmniejszania dodatków specjalnych

1 - analiza kwartalnych, półrocznych 1 rocznych sprawozdań finansowych 1 gospodarczych, referowanych przez Głównego Ksleggowego Poliklinik1.

Fot. 1. Instrukcja o organizacji i zakresie czynności Kolegium Polikliniki KC PZPR i CRZZ, 12 VII 1971, sygn. 426/1, fot. B.A. Kuliński 
mniej jedno na kwartał. Omawiano wówczas takie kwestie, jak: kandydatury do nagród i odznaczeń, bieżące funkcjonowanie Polikliniki, wnioski usprawniające pracę, wysokość dodatków specjalnych, analizy sprawozdań finansowych i gospodarczych. Uchwały były podejmowane większością głosów, a w przypadku równej liczby głosów decydował kierownik. Regulamin Kolegium zabezpieczał kierownika na wypadek podjęcia uchwały niezgodnej z jego stanowiskiem, wówczas sprawe przekazywano do niepodlegającej zakwestionowaniu decyzji Komisji ds. Polikliniki. Jak wspomniałem wyżej, część ostatecznych decyzji w sprawach procedowanych przez Kolegium i tak była zależna od Komisji ds. Polikliniki. W Poliklinice działały także: Kasa Zapomogowo-Pożyczkowa, POP PZPR, Rada Zakładowa Związku Zawodowego Pracowników Służby Zdrowia czy Koło Towarzystwa Przyjaźni Polsko-Radzieckiej, jednak nie zachowały się materiały dotyczące ich funkcjonowania.

\section{Siedziba główna, filia, punkty}

Nowo utworzona placówka swoją główną siedzibę przejęła w 1955 r. po Poliklinice CRZZ. Było to 2,5 piętra w budynku przy ul. Mazowieckiej 6/8 w Warszawie. Mimo wykonanej jeszcze w 1954 r. adaptacji nieduże pomieszczenia $z$ trudem spełniały wymogi świadczenia usług medycznych - budynek powstał z przeznaczeniem na Hotel Związkowy. Praktycznie od początku działalności starano się pozyskać więcej lokali, co udało się dopiero w październiku 1973 r. Mimo tego Poliklinika wciąż nie dysponowała całym budynkiem. Swoje pomieszczenia miały w nim jeszcze: Zarząd Główny Związku Zawodowego Pracowników Państwowych i Społecznych (formalny gospodarz obiektu), Film Polski i Centrala Wynajmu Filmu. W 1965, 1969 i 1974 r. przeprowadzono większe remonty. Prawdopodobnie modernizacji było jednak więcej, ponieważ były one wymagane przez obowiązujące przepisy. Nakazywały one odświeżanie ścian placówek medycznych przynajmniej co dwa lata, a w szczególnie uzasadnionych przypadkach maksymalnie co cztery. Poliklinika zresztą nader często korzystała z tej drugiej możliwości, motywując ją problemami natury finansowej.

Poliklinika posiadała jedną filię - Poradnię dla Dzieci i Młodzieży (ul. Wiejska 18, Warszawa). Była to placówka w pełni zależna budżetowo i administracyjnie od Polikliniki. $W$ rocznych preliminarzach i sprawozdaniach kierownictwo uwzględniało środki na bieżące utrzymanie budynku (czynsz, centralne ogrzewanie, woda, gaz, prąd, telefon) oraz jego okresowe remonty. 
Poliklinika prowadziła także punkty medyczne w następujących lokalizacjach:

- Gabinet zabiegowy KC PZPR (ul. Nowy Świat 6/12, Warszawa),

- Gabinet zabiegowy CRZZ (ul. Kopernika 36/40, Warszawa),

- Izolatka WSNS (ul. Belwederska 26/30, Warszawa),

- Gabinet zabiegowy WSNS (ul. Bagatela 2, Warszawa),

- Gabinet zabiegowy WSNS (ul. Nowy Świat 4, Warszawa),

- Gabinet zabiegowy WSNS (ul. Rozbrat 44a, Warszawa),

- Gabinet zabiegowy WSNS (ul. Nowy Świat 12, Warszawa, punkt przy internacie),

- Ośrodek Kursów Partyjnych (OKP) KC PZPR (ul. Szara 10a, Warszawa).

Zachowany regulamin organizacyjny Punktu przy CRZZ pozwala domniemywać jak mogły być zorganizowane pozostałe ${ }^{6}$. Składał się on z gabinetu zabiegowego, magazynu podręcznego i poczekalni. Dyżur pełniła w nim jedna pielęgniarka, będąca pracownicą Polikliniki. Koszty wyposażenia i utrzymania Punktu leżały po stronie CRZZ. Pacjentami byli pracownicy budynku oraz, w nagłych wypadkach, osoby przebywające na jego terenie. Punkt był czynny od poniedziałku do piątku w godzinach 10-16, a w soboty 10-14. Do jego głównych zadań należały: pierwsza pomoc przedlekarska, wzywanie pogotowia, wykonywanie prostych zabiegów, podawanie leków w formie zastrzyków, wydawanie leków przeciwbólowych, nasercowych i uspokajających, konwojowanie pacjentów do szpitala lub domu oraz nadzór zdrowotny nad personelem bloku żywnościowego CRZZ. Pozostałe punkty musiały być zorganizowane na podobnych zasadach, tj. koszty wyposażenia i bieżącego utrzymania ponosiła instytucja, w której znajdował się punkt. Natomiast źródła finansowania pensji personelu pozostają niejasne. $\mathrm{Z}$ dokumentów, takich jak regulamin punktu przy CRZZ czy roczne sprawozdania, wynika, że pracownicy ci byli zatrudnieni i opłacani przez Poliklinikę, a jedynie ewentualne dodatki specjalne pokrywane były z subwencji KC PZPR i CRZZ. Z protokołów kontroli i rocznych sprawozdań wynika jednak inna praktyka, np. w przypadku WSNS było to istotnie zatrudnienie w Poliklinice i wypłacanie przez nią poborów, ale środki na ten cel pochodziły w całości z budżetu WSNS7.

${ }^{6}$ Poliklinika Pracowników KC PZPR i CRZZ, Regulamin wewnętrzny Punktu Pielęgniarskiego przy CRZZ, b.d. [1968], sygn. 426/4.

7 Poliklinika Pracowników KC PZPR i CRZZ, Roczne sprawozdania ogólne z działalności Polikliniki Pracowników KC PZPR i CRZZ (1969, 1972-1976), sygn. 426/6, poz. 1-7; dokumentacja dot. kontroli, sygn. 426/11 i 426/12. 
W ramach Polikliniki działał również Punkt Apteczny. W początkowym okresie mieścił się na terenie Poradni dla Dzieci i Młodzieży przy ul. Wiejskiej 18, następnie przeniesiono go do głównego budynku Polikliniki przy ul. Mazowieckiej 6/8. Dopiero w maju 1970 r. uzyskał status Apteki leków gotowych (nr 15).

\section{Zakres działalności Polikliniki Pracowników KC PZPR i CRZZ}

Pacjentami Polikliniki byli pracownicy KC PZPR i CRZZ, stołecznych aparatów partyjnych i związkowych, członkowie ich rodzin oraz uprawnieni renciści. „W początkowym okresie pacjentami Polikliniki byli ludzie aktywu partyjnego i związkowego, którzy mieli utracone zdrowie pracą konspiracyjną w okresie wojennym"s. KC PZPR i CRZZ nadawały także uprawnienia do leczenia w Poliklinice instytucjom $\mathrm{z}$ nimi bezpośrednio niezwiązanym. Nie zapomniano również o pracownikach Polikliniki i ich rodzinach. Łączna liczba uprawnionych do korzystania z usług Polikliniki była zmienna. Przeważnie jednak w ujęciach miesięcznych kształtowała się na poziomie $12-13$ tys. ${ }^{9}$ Należy jednak podchodzić ostrożnie do tych liczb, ponieważ placówka borykała się z problemem bieżącej aktualizacji danych.

Do statutowych zadań Polikliniki należało udzielanie stacjonarnej, nieodpłatnej pomocy uprawnionym pacjentom zgłaszającym się do poradni. Oprócz tego, w ograniczonym zakresie, świadczono wyjazdową opiekę domową. Drugą istotną gałęzią działalności było przeprowadza-



Fot. 2. Kronika Polikliniki KC PZPR i CRZZ i Przychodni Pracowniczej KC PZPR i CRZZ, 1971-1980, sygn. 425/19, k. 1, fot. B.A. Kuliński

${ }^{8}$ Przychodnia Pracownicza KC PZPR i CRZZ, Kronika Polikliniki Pracowników KC PZPR i CRZZ, sygn. 425/19, s. 1.

9 Poliklinika Pracowników KC PZPR i CRZZ, Ilościowe wykazy uprawnionych do korzystania z opieki medycznej w Poliklinice Pracowników KC PZPR i CRZZ (19731976), sygn. 426/19, poz. 1-13. 
nie badań wstępnych i okresowych pracowników uprawnionego aparatu partyjnego i związkowego. Do obowiązków Polikliniki należało także zabezpieczanie medyczne wydarzeń organizowanych przez KC PZPR i CRZZ, takich jak np. VIII Kongres Związków Zawodowych ${ }^{10}$.

W Poliklinice pracowano od poniedziałku do soboty, na dwie zmiany, w godzinach 7-20 (poradnie przy ul. Mazowieckiej, stan z lutego 1971 r.). Zatrudniano pracowników na cały etat lub jego część. Świadczono pomoc w następujących specjalizacjach: interna, stomatologia, pediatria, ortopedia, okulistyka, laryngologia, ginekologia, kardiologia, dermatologia, radiologia, neurologia, psychiatria, urologia, endokrynologia, cytologia, chirurgia, gastrologia, reumatologia, protetyka. Personel uzupełniało ok. 30 pielęgniarek, położna i starszy felczer. Ponieważ Poliklinika nie współpracowała z żadną jednostką o charakterze szpitalnym, pacjenci wymagający hospitalizacji trafiali, przynajmniej oficjalnie, na ogólnych zasadach do powszechnie dostępnych placówek.

\section{Przekształcenie w Przychodnię Pracowniczą KC PZPR i CRZZ}

Przychodnia pod nazwą Poliklinika Pracowników KC PZPR i CRZZ zakończyła swoją działalność 31 grudnia 1976 r. Decyzją Ministra Zdrowia i Opieki Społecznej (MZiOS) z 30 listopada 1976 r. w jej miejsce powołano Przychodnię Pracowniczą KC PZPR i CRZZ. Poliklinika rozliczyła swoją działalność finansowo-gospodarczą sprawozdaniem sporządzonym po 30 czerwca 1977 r. ${ }^{11}$ Decyzja MZiOS o przekształceniu w samodzielną jednostkę budżetową zapadła już 15 października 1975 r. W notatce do Kierownika WO KC PZPR z 31 października 1975 r. dyrektor Polikliniki optymistycznie napisał, że rozpoczęcie pracy według nowych zasad miało nastąpić od 1 stycznia 1976 r. ${ }^{12}$ $\mathrm{Z}$ poczynionych ustaleń wynikało, że nowo utworzona Przychodnia miała podlegać Przewodniczącemu Prezydium Miejskiej Rady Narodowej m.st. Warszawy (prezydentowi miasta). Nadzór KC PZPR

${ }^{10}$ Poliklinika Pracowników KC PZPR i CRZZ, Notatka stużbowa dla Wydziału Oświaty, Kultury i Prasy CRZZ w sprawie zabezpieczenia medycznego Zespołów Artystycznych występujacych w czasie VIII Kongresu Zwiazków zawodowych, b.d. [1976], sygn. 426/21.

11 Poliklinika Pracowników KC PZPR i CRZZ, Sprawozdanie z zakończenia działalności finansowo-gospodarczej b. Polikliniki Pracowników KC PZPR i CRZZ, b.d. [1977], sygn. 426/10.

12 Poliklinika Pracowników KC PZPR i CRZZ, Dokumenty dot. przekształcenia Polikliniki Pracowników KC PZPR i CRZZ w Przychodnię Pracowniczą KC PZPR i CRZZ, sygn. 426/2, poz. 1 . 
i CRZZ pozostawał bez zmian. Finansowanie miały zapewniać: stołeczny Wydział Zdrowia, czyli jednostka nadrzędna wobec dzielnicowego WZ. Budżet, tak jak dotychczas, uzupełniać miały dotacje KC PZPR i CRZZ. Starano się wówczas o uzyskanie statusu zakładu budżetowego, co umożliwiłoby uwolnienie spod zależności finansowej od wyżej wymienionych instytucji. Równolegle Kierownictwo Polikliniki czyniło starania o przejście placówki pod bezpośredni zarząd $\mathrm{MZiOS}^{13}$. Takie rozwiązanie skutkowałoby zwiększeniem budżetu i poszerzeniem autonomii. Kolejny rok Poliklinika przepracowała jednak $\mathrm{w}$ dotychczasowym kształcie, co wynikało z braku pieniędzy. Środki na ten cel udało się zaplanować na 1977 r., co pozwoliło na wydanie 30 listopada 1976 r. decyzji o powołaniu Przychodni Pracowniczej KC PZPR i CRZZ. Statut nowej jednostki zatwierdzono 17 grudnia 1976 r. ${ }^{14}$ Przychodnia w nowym kształcie organizacyjnym zaczęła funkcjonować od 1 stycznia 1977 r. Od tego czasu instytucja podlegała organizacyjnie i finansowo bezpośrednio MZiOS. Przejęła pracowników i cały majątek, którymi dotychczas dysponowała Poliklinika. Zlikwidowało to stare problemy, ale także utworzyło nowe. Pierwszym z nich była np. kwestia wypłacanych od czasu powstania Polikliniki dodatków specjalnych, które w nowej rzeczywistości miały częściowo ulec likwidacji ${ }^{15}$.

Dzięki zachowanym egzemplarzom statutu nieco więcej można powiedzieć o organizacji Przychodni ${ }^{16}$. Na jej czele stał dyrektor, mając do pomocy zastępców: ds. opieki zdrowotnej, ds. administracyjnoekonomicznych i przełożoną pielęgniarek. Dyrektor zarządzał działami: Opieki Zdrowotnej i Ekonomiczno-Administracyjnym. W skład tego ostatniego działu wchodziły sekcje: ekonomiczno-finansowa, gospodarczo-administracyjna, służby pracowniczej i samodzielne stanowisko radcy prawnego. Organem ,programującym, doradczym i opiniodawczym" była Rada Przychodni ${ }^{17}$. Składała się ona z: dyrektora (przewodniczący), przedstawicieli KC PZPR i CRZZ, zastępcy dyrektora, przełożonej pielęgniarek, kierowników komórek organizacyjnych Przychodni oraz przedstawicieli POP PZPR i Rady Zakładowej. Rada zajmowała się takimi zagadnieniami, jak: organizacja pracy, projektowanie i planowanie budżetu, podział etatów, rozmieszczenie

\footnotetext{
13 Tamże, poz. 1-6.

${ }_{14}$ Tamże, poz. 6.

15 Tamże, poz. 5 oraz Przychodnia Pracownicza KC PZPR i CRZZ, sygn. 425/2, poz. 1.

${ }_{16}$ Przychodnia Pracownicza KC PZPR i CRZZ, Statut Przychodni Pracowniczej KC PZPR i CRZZ, 1976, sygn. 425/3, poz. 2.

17 Tamże.
} 


\section{STATUT \\ PRZVCMOONI PRACQNJGZES KG P.Z.P.R. 2 C.R.Z.z.}

51

Przychodnda Pracownsozo ic pzps \& crzz zwana dazos "Przychodnso" dztaka no podetawse:


a dnsa... 30 listuparare $1976 \mathrm{r} . . .$.

2. Nanzojozogo otatutu zatuLordzongo przoz, nsnLozraj zorowio



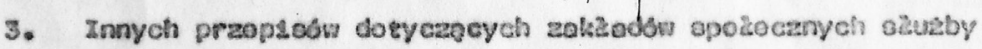
zdrowsa, pankstwourych jodnootok organizacyjnyeh a jedrootok budzotouych,

\section{2}

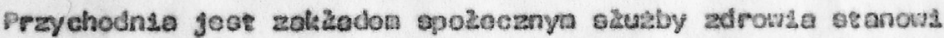
oanodzselng jodnootke organlzacy jno i bucketovo podlogla Minsotrows zdrowla s OpLoks spozocanoj.

\section{3}

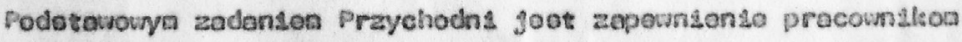
contralnego \& otoslecznego oporazu partyjnogo \& zwsozkonogo. ezizonkon 4 ch rodzin oraz upravnLonya ronctoton do korzyotania ze owdadezon adrowoenych.

2 optols adrowotnog podotavowog ta eakrocso:

a. Indynsdualnych abulatorygnych swladezon zapoblogavazo2oczndezych przez poradnto ogsine, dzlectece s pozotniczo ginokologicano foplotco anbulatorygna/ oraz $"$ razto obzoznoy choroby w alojocu zansoozlanda Eyllio no obszarzo w.oe. Larazary /optoke dowowa/.

b. anbulatoryjmych dvLadezon zapoblogawczo-1eczn\&czych w zolsrosie aconatologts wraz z protozowanion:

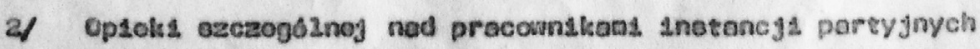
I zusgakowych prowadzonoj w Órodoutolu procy \& nauks il zotsroese:

a. Indywsdualnyeh EvLadezah Lecansczych podotowowych,

Fot. 3. Statut Przychodni, 17 XII 1976, sygn. 425/3, poz. 2, fot. B.A. Kuliński 
lokalowe, plan remontów, wyposażenie, okresowa ocena działalności Przychodni. W statucie nie wspomniano o nadzorze wyższego rzędu. Wobec wejścia przedstawicieli KC PZPR i CRZZ do Rady Przychodni oraz przeprowadzenia przez MZiOS oraz Centralną Komisję Rewizyjną PZPR kontroli, organ w postaci Komisji ds. Przychodni nie został utrzymany.

\section{Siedziba i zakres działalności}

Przychodnia Pracownicza KC PZPR i CRZZ świadczyła opiekę w następujących lokalizacjach:

- siedziba główna (ul. Mazowiecka 6/8, Warszawa),

- Poradnia dla Dzieci i Młodzieży (ul. Wiejska 18, Warszawa),

- KC PZPR (ul. Nowy Świat 6/12, Warszawa), gabinety: lekarski, zabiegowy, dentystyczny,

- Komitet Warszawski PZPR (ul. Chopina 1, Warszawa), gabinety: lekarski, dentystyczny,

- CRZZ (ul. Kopernika 36/40, Warszawa), gabinety: lekarski, zabiegowy, dentystyczny,

- WSNS (ul. Bagatela 2, Warszawa), gabinety: lekarski, pielęgniarski,

- WSNS (ul. Belwederska 26/30, Warszawa), gabinety: lekarski, zabiegowy, dentystyczny, izolatki,

- OKP KC PZPR (ul. Szara 10a / ul. Rozbrat 44a, Warszawa), gabinety: lekarski, zabiegowy,

- MZiOS (ul. Miodowa 15), gabinety: lekarski, zabiegowy, dentystyczny, poradni dla kobiet.

Przejście pod bezpośredni zarząd MZiOS i nowa nazwa były zasadniczymi zmianami, do których doszło po 1 stycznia 1977 r. W dalszym ciągu opieką medyczną Przychodni objęci byli pracownicy KC PZPR i CRZZ, stołecznych aparatów partyjnych i związkowych, członkowie ich rodzin oraz uprawnieni renciści. Systematycznie rosła liczba uprawnionych, w 1979 r. było ich już prawie 19 tys. ${ }^{18} \mathrm{~W}$ ślad za tym zwiększano liczbę personelu. Zakres świadczonych usług pozostał jednak bez zmian. Znacznym usprawnieniem w skutecznym świadczeniu opieki zdrowotnej było podjęcie stałej współpracy z Zespolonym Szpitalem Klinicznym Centrum Medycznego Kształcenia Podyplomowego

18 Przychodnia Pracownicza KC PZPR i CRZZ, Ilościowe wykazy uprawnionych do korzystania z opieki medycznej w Przychodni Pracowniczej KC PZPR i CRZZ (1977-1980), sygn. $425 / 9$, poz. $1-15$. 
SPRAWOZDANIE

2 DZTALALNOSCI PRZYCHODNI PRACOMNICZET KC PZPR I CRZZ w 1279 roku

I. Przychodnia Pracomicza KC PZPR I CRzz sprawowała opieke medyczna nad 18,482 osobami.

Wedzug zestawien na dzien 31.12.1979 r. upramionych do korzystania z Przychodni byzo:

$$
\begin{aligned}
& \text { przez Komitet Centralny PZPR - } 9.630 \text { osób } \\
& \text { w tym: - pracowniey } \\
& \text { - ezłonkowle rodzin dorośl1 - } 3.223 \\
& \text { - członkowie rodzin dziec1 - } 1.692 \\
& \text { - rencistów - } 678 \\
& \text { przez Centralną Radę Związków Zawodowych - } \quad 8.549 \\
& \text { w tyms - pracowników - } 3.539 \\
& \text { - członków rodzin dorośli - } 3.170 \\
& \text { - członków rodzin dziec1 - } 1.140 \\
& \text { - rencistón - } 700
\end{aligned}
$$

Przychodnia prowadz1 swą dziazalnośc w 9 punktach miasta: głóma baza wraz z administzacją znajduje się przy ul. Miazowieck1ej $6 / 8$, gdzie czynnych jest 6 gabinetów internistycznych, 3 gabinety dentystyezne, gabinet protetykd wraz z pracownią protetyczną, gabinet ginekologiczny oraz następujące gabinety poradnie specjalistyezne: okwiistyika, laryngologia, neurologia, urologia, psychatria, dematologia, gastrologia, kardiologia, reumatologia, chirurgla ogólna 1 urazowo ortopedyczna. Poza tym gablnet Iizykoterap 11 masazu oraz pracomile diagnostyjd. laboratoryjnej, radiodiagnostyki ogólnej 1. rtg dentystyezny.

Przy ul. Wiejskiej 18 znajduje się Poradnia Dzieelęca prowadząca w zasadzle tylko leeznictwo dzlecl ehorych / 2 gabinety lekarskle + gabinet zablegowy/ gabinet dentystyczny dla dziecl, gabinet laryngologil i chirurgil dzieclęceJ oraz pracownia radiodiagnostyki dla dzieel i dla doroszlych.

Pozostaze placówki to 7 poradni przyzakzadowych:

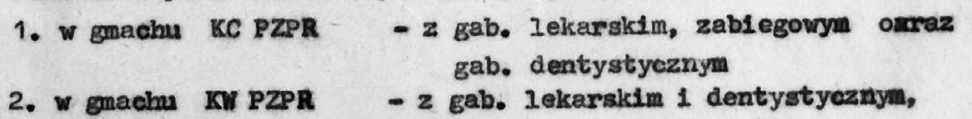

2. W gmachm KW PZPR - 2 gab. lekarskim I dentystycznym,

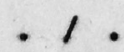

Fot. 4. Sprawozdanie z działalności Przychodni Pracowniczej KC PZPR i CRZZ w roku 1979, b.d. [1980], sygn. 425/6, poz. 4, fot. B.A. Kuliński 
(CMPK) (obecnie Samodzielny Publiczny Szpital Kliniczny im. prof. W. Orłowskiego CMKP, ul. Czerniakowska 231, Warszawa).

\section{Dalsze losy}

Rozporządzeniem MZiOS z 12 grudnia 1980 r. Przychodnia Pracownicza KC PZPR i CRZZ otrzymała nazwę Międzyzakładowa Przychodnia Pracownicza (MPP) ${ }^{19}$. Była to w znacznej mierze reakcja na planowaną z końcem 1980 r. likwidację CRZZ (oraz całego Zrzeszenia Związków Zawodowych). Pracownicy związków (od 1984 r. Ogólnopolskie Porozumienie Związków Zawodowych) nadal jednak korzystali z Przychodni, podobnie zresztą jak pracownicy KC PZPR i MZiOS, jednakże pacjentami byli pracownicy łącznie blisko 60 instytucji, co także nie mogło pozostać bez wpływu na zmianę nazwy.

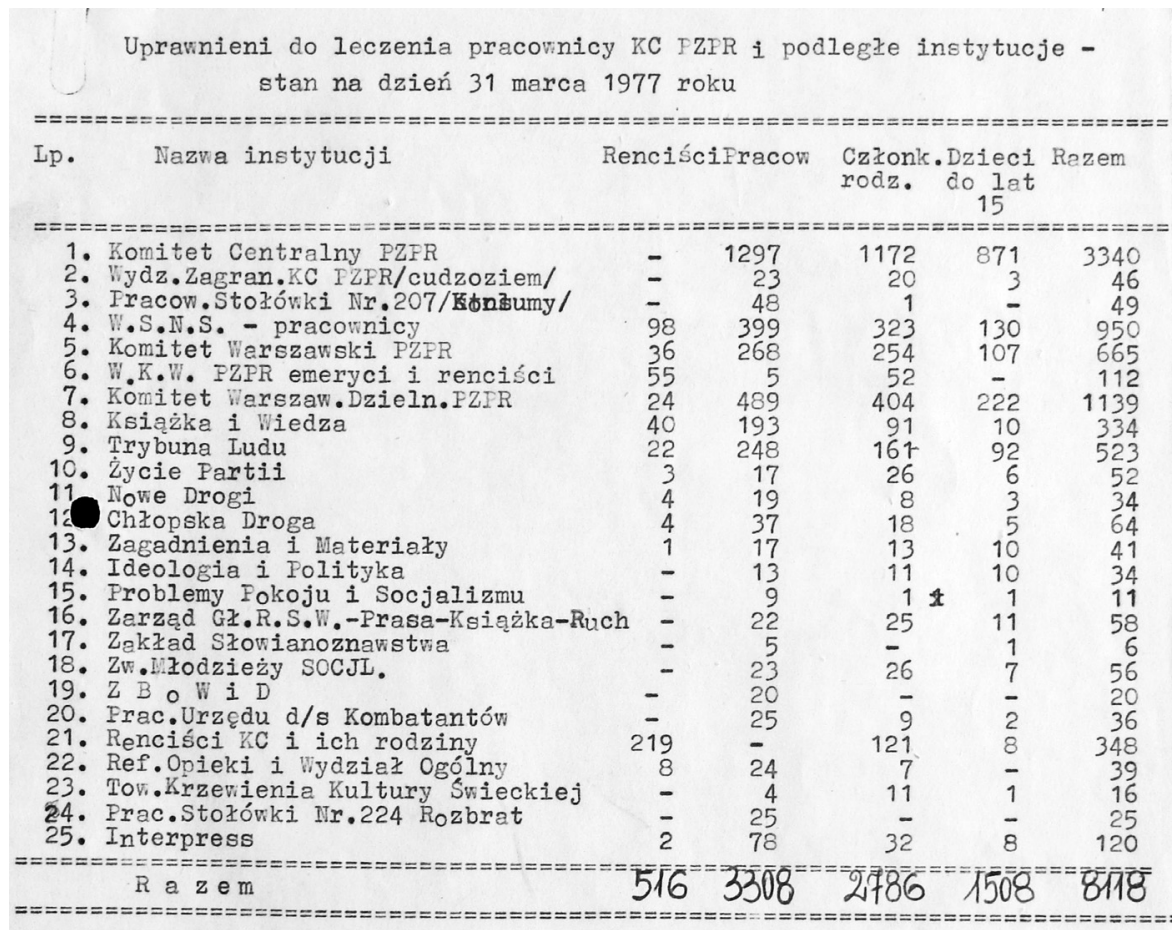

Fot. 5. Uprawnieni do leczenia pracownicy KC PZPR i podlegle instytucje - stan na dzień 31 marca 1977, b. d. [1977], sygn. 425/9, poz. 2, fot. B.A. Kuliński

19 Przychodnia Pracownicza KC PZPR i CRZZ, Zmiany organizacyjne w Przychodni Pracowniczej KC PZPR i CRZZ (1977-1980), sygn. 425/2, poz. 5. 
Pod nowym szyldem Przychodnia przetrwała transformację ustrojową. Zmiany w finansowaniu służby zdrowia, a szczególnie odejście od utrzymywania branżowych przychodni, doprowadziły do przekształcenia MPP w Przychodnię Mazowiecką (PM). Znalazła się ona pod zarządem administracji samorządowej województwa mazowieckiego. W ramach kolejnej restrukturyzacji PM została połączona z Samodzielnym Publicznym Zakładem Opieki Zdrowotnej „Lecznica Centrum”, którą z kolei przyłączono w styczniu 2012 r. do SP ZOZ Centrum Leczniczo-Rehabilitacyjne i Medycyny Pracy „ATTIS” ${ }^{20}$. Od 6 września 2013 r. do chwili obecnej placówka działa jako spółka prawa handlowego pn. Centrum Leczniczo-Rehabilitacyjne i Medycyny Pracy ATTIS Sp. z o.o. (Centrum ATTIS) i pozostaje w 100\% placówką publiczną, podległą Samorządowi Województwa Mazowieckiego.

Niniejsze opracowanie zdecydowanie nie wyczerpuje tematu opieki medycznej dla pracowników centralnego aparatu partyjnego i związkowego w PRL. Pozyskane z materiałów powstałych w Poliklinice i Przychodni informacje wymagają przede wszystkim uzupełnienia i konfrontacji ze źródłami wytworzonymi w organach i instytucjach nadzorujących te placówki oraz z nimi powiązanych (WO KC PZPR, ZZZ, CRZZ, WZ, MZiOS, WSNS). Dalszej wiedzy o organizacji punktów terenowych mogą dostarczyć dwa niepublikowane maszynopisy dotyczące siedziby KC PZPR (ul. Nowy Świat 6/12, Warszawa): Rozkład i funkcje pomieszczeń w gmachu KC PZPR (b.d.) i Inwentaryzacja ogólna budynku po bytym KC PZPR wraz z opisem stanu technicznego budynku wykonana przez Komisje ds. zagospodarowania obiektu b. KC PZPR (sierpień 1990) ${ }^{21}$. Ponadto uporządkowania i opracowania wymaga zespół akt wytworzonych przez Międzyzakładową Przychodnię Pracowniczą - bezpośredniego kontynuatora działalności Przychodni Pracowniczej KC PZPR i CRZZ. Wymienione powyżej działania skalą, materiałem do przebadania i spodziewanymi wynikami wykroczą poza ramy przewidziane dla pojedynczego artykułu naukowego. Moim zdaniem zagadnienie zasługuje, aby zająć się nim w ramach szerszej monografii.

${ }^{20}$ Uchwała Sejmiku Województwa Mazowieckiego Nr 103/11 z dnia 11 lipca 2011 r., w sprawie połączenia Samodzielnego Publicznego Zakładu Opieki Zdrowotnej „Lecznica Centrum" z Centrum Leczniczo-Rehabilitacyjnym i Medycyny Pracy ATTIS - Samodzielnym Publicznym Zakładem Opieki Zdrowotnej.

${ }^{21}$ Oba maszynopisy są przechowywane w dziale administracyjnym Centrum Bankowo-Finansowego w Warszawie (ul. Nowy Świat 6/12), informacja za: A. Skalimowski, Dom Partii. Historia gmachu KC PZPR w Warszawie, Warszawa 2010, s. 117 i 125. 


\section{Nota bibliograficzna}

Akta dotyczące obydwu instytucji zostały odnalezione w 2016 r. podczas porządkowania dokumentacji, która miała zostać przekazana do brakowania. Zespoły, biorąc pod uwagę zsumowane lata funkcjonowania obu instytucji (1955-1980), zachowały się w szczątkowym stanie - niecały metr bieżący akt. Obecnie znajdują się w Archiwum Zakładowym Centrum ATTIS (spisy zdawczo-odbiorcze nr 425 i 426), gdzie oczekują na przekazanie do właściwego archiwum państwowego. Dla zrozumienia, dlaczego zespoły dotrwały do naszych czasów $\mathrm{w}$ tak mocno okrojonym rozmiarze, niezbędne jest przytoczenie kilku determinujących ten stan faktów.

Wiadomo, że w strukturach Polikliniki i Przychodni nie działały wydzielone komórki zajmujące się stricte gromadzeniem dokumentacji (archiwum zakładowe, składnica akt). Za bieżącą dokumentację medyczną odpowiedzialne były rejestratorki, których pracę nadzorowała kierowniczka rejestracji. Początkowo prawdopodobnie właśnie spośród tego personelu wyznaczano osobę zajmującą się dokumentacją medyczną (i najprawdopodobniej wytworzoną przez administrację) wymagającą zarchiwizowania. Do 1969 r., o ile zatrudniano oddzielnego pracownika dedykowanego do tych zadań, o tyle uwzględniano go $\mathrm{w}$ zestawieniach wydatków na pensje pod wspólną pozycją „pracownicy administracyjni”. Dopiero w preliminarzach budżetowych na lata 1969-1972 (kolejne nie zawierają już tak szczegółowych danych) uwzględniono płace dla jednej archiwistki, która pracowała 3 godziny dziennie $^{22}$. Za pracę pobierała miesięczną pensję w wysokości ówczesnych 600 zł. Informacji o zakresie jej obowiązków oraz powodów zatrudnienia w niepełnym wymiarze godzin dostarcza Notatka wyjaśniajaca do preliminarza budżetowego na 1972 r.: „Stałej konserwacji wymagają tysiące teczek z kartami choroby, ponieważ większość lekarzy obchodzi się z nimi niedbale. Karty trzeba też systematycznie uzupełniać dodatkowymi arkuszami, porządkować, zszywać itp. Rencistka, nawiasem mówiąc była wieloletnia pracownica rejestracji Polikliniki, zatrudniona na pół etatu doskonale wykonuje te prace, a Poliklinika może poszczycić się wzorowo utrzymaną dokumentacją chorobową"23.

Zachowało się tylko jedno źródło bezpośrednio dotyczące obrotu dokumentacją. (Wykaz akt dla Przychodni Pracowniczej KC PZPR

22 Poliklinika Pracowników KC PZPR i CRZZ, Preliminarze budżetowe (1968-1976), sygn. $426 / 8$, poz. $2-9$.

${ }^{23}$ Tamże, poz. 9, s. 54. 
i CRZZ - sygn. 425/5). Mam jednak uzasadnione wątpliwości czy wobec lekceważącego stosunku do merytorycznej spójności i kompletności dokumentacji wykaz ten był tylko martwą literą. Podczas kolejnych kontroli stwierdzano braki takich dokumentów, jak: roczne sprawozdania finansowe, zakresy obowiązków poszczególnych pracowników. Kontrolerzy podważali także aktualność statutu i niektórych regulaminów. W przypadku dokumentacji medycznej do częstych uchybień zaliczały się: nieprawidłowe prowadzenie rejestrów, błędy w zestawieniach statystycznych, brak informacji o rozpoznanej jednostce chorobowej, brak oznaczenia typu wizyty (stacjonarna/domowa) oraz ogólny nieporządek w kartotekach. Zachowane protokoły kontroli dotyczyły jedynie weryfikacji dokumentacji pod względem merytorycznym.

Dzięki kronikarskiemu przekazowi nieco więcej można powiedzieć o postępowaniu z dokumentacją medyczną w rejestracji. Uprawnienie do korzystania z przychodni było potwierdzane w formie występowania indywidualnej dokumentacji medycznej pacjenta w kartotekach. W związku z tym musiano zakładać kartę, nawet gdy pacjent ani razu nie korzystał z porady lekarskiej. Uprawnienia aktualizowano w oparciu o okresowo przesyłane spisy lub przez indywidualne zawiadomienia przychodzące z poszczególnych instytucji. W praktyce było to nieskuteczne i często powodowało korzystanie z usług medycznych osób, które z różnych powodów utraciły uprawnienia. Osobiste i telefoniczne zapisy na wizyty odnotowywano w rejestracji w zeszytach-terminarzach poszczególnych lekarzy i gabinetów pomocniczych. Prowadzono również ewidencje: przyjętych pacjentów (osobno stomatologicznych) oraz wystawionych zwolnień lekarskich. Indywidualna dokumentacja medyczna początkowo była sporządzana w sposób ciągły zgodnie $\mathrm{z}$ chronologią udzielanych porad. Wraz ze wzrostem liczby konsultacji metoda ta okazała się niepraktyczna. $W$ jej miejsce wprowadzono formularze-karty, w których wyodrębniono miejsce dla poszczególnych specjalizacji. Jedynie historie wizyt pacjentów stomatologicznych prowadzono osobno. Bieżąca dokumentacja składowana była w szafach-kartotekach w układzie alfabetycznym. Do gabinetów dostarczano ją bezpośrednio przed dyżurem lekarza przez gońca. Po dyżurze była zwracana do rejestracji. W $1970 \mathrm{r}$. w ramach remontu budynku przychodni wymieniono szafy kartotekowe. Według kroniki nowe sięgały do sufitu, a karty wyciągano, korzystając z przenośnych stopni. Dla ułatwienia pracy wprowadzono kolorowe oznaczenia kart. Niebieskim oznaczano czynnych zawodowo uprawnionych, różowym ich rodziny, a żółtym rencistów. Pod koniec lat 70. wprowadzono zbiorczą 


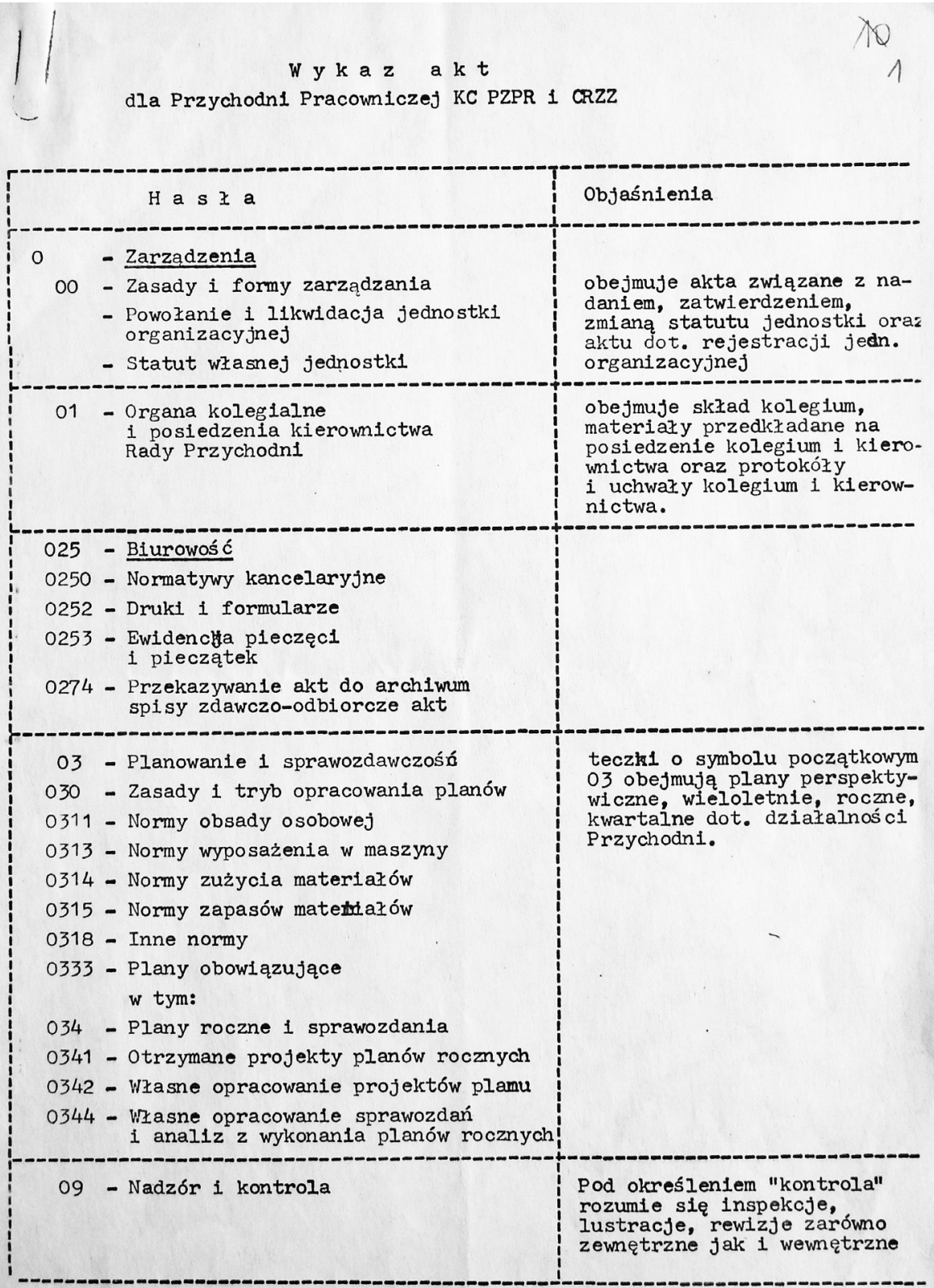

Fot. 6. Wykaz akt dla Przychodni Pracowniczej KC PZPR i CRZZ, b.d., sygn. 425/5, fot. B.A. Kuliński 
dokumentację pracowników i ich rodzin. Oddzielnie składowano klisze RTG. Opisywano je imieniem i nazwiskiem wraz z odwołaniem do głównej dokumentacji pacjenta. Wyniki badań laboratoryjnych i EKG również składowano osobno, przy czym w przypadku braku odbioru po upływie około dwóch tygodni dołączano je do głównej dokumentacji medycznej pacjentów. W rejestracji trzymano także, w specjalnych kasetach, druki zwolnień lekarskich.

Należy domniemywać, że dokumentacja była w związku z kolejnymi przeprowadzkami stopniowo niszczona. Brakowanie dokumentacji raczej nie odbywało się protokolarnie. Przeważająca część dokumentacji została przejęta podczas kolejnych przekształceń przez spadkobierców prawnych, a następnie $\mathrm{w}$ związku z utratą przydatności, mniej lub bardziej formalnie brakowana. Tak stało się na pewno $\mathrm{z}$ indywidualną dokumentacją medyczną, której okres przechowywania wynosił ówcześnie 10 lat od daty ostatniej odnotowanej w karcie wizyty, oraz zbiorczą dokumentacją medyczną (księgi przychodni, zeszyty zapisów na wizyty itp.). Na podobnych zasadach postapiono $\mathrm{z}$ dokumentacją osobowo-płacową, przy czym $z$ reguły nie uległa ona brakowaniu, lecz rozproszyła się po archiwach zakładowych kolejnych instytucji przejmujących pracowników. W pojedynczych przypadkach tego typu dokumentacja przeszła przez wszystkich kolejnych następców prawnych Polikliniki KC PZPR i CRZZ i znajduje się w aktach osobowo-płacowych Centrum ATTIS.

\section{Bibliografia}

Horst W., Kancelarie i archiwa Centralnego Komitetu Wykonawczego Polskiej Partii Socjalistycznej, Komitetu Centralnego Polskiej Partii Robotniczej i Komitetu Centralnego Polskiej Zjednoczonej Partii Robotniczej (1944-1990), Naczelna Dyrekcja Archiwów Państwowych, Warszawa 2007.

Janowski W., Kochański A., Informator o strukturze i obsadzie personalnej centralnego aparatu PZPR, 1948-1990, Instytut Studiów Politycznych PAN, Warszawa 2000.

Mróz T. (red.), Uwarunkowania systemu opieki zdrowotnej w Polsce. Aspekty prawne i socjologiczne, Temida 2, Białystok 2012.

Skalimowski A., Dom Partii. Historia gmachu KC PZPR w Warszawie, Neriton, Warszawa 2010. 